\title{
Mimari Yapılarda Görülen Taş Kabartma Süslemelerin Din ve Sanat İlişskisi Açısından Değerlendirilmesi (Aksaray İli Güzelyurt Örneği)
}

\author{
The Evaluation of Stone Relief Ornaments in Architectural Structures in the \\ context of the Relationship Between Religion and Art (The Example of \\ Guzelyurt District in Aksaray Province)
}

\section{Gamze Uray}

Öğr. Gör., Aksaray Üniversitesi Güzelyurt Meslek Yüksekokulu Mimari Dekoratif Sanatlar, karamangamze3@gmail.com

\section{$\ddot{\mathbf{O} z}$}

İnsanoğlunun, barınma ve korunma ihtiyacından dolayı, yaşadığı yeri ve çevreyi düzenleme isteği mimarlık eylemini başlatmış, yerleşik hayata geçmesiyle de ahşap, taş gibi malzemeleri kullanarak mimari yapıların gelişim sürecini hızlandırmıştır. Mimari yapının en temel biçimlendirme elemanı olan taş, aynı zamanda bir süsleme elemanı olarak kullanılmış din, kültür ve estetik kaygılar ile birleşerek, duygu ve düşünceleri anlatan bir araç olmuştur. Tarih öncesi çağlardan başlayarak günümüze kadar gelişim süreci içine giren mimari yapılar, her türlü toplumsal değişimden etkilenmiştir. Özellikle din ve sanat gibi kavramlar, mimari yapıların değişip gelişmesinde önemli rol oynamıştır. Din ve sanat; birbirine zıt iki kavram gibi gözükse de bu iki kavramın birbirleriyle olan etkileşimini göz ardı etmek yanlış olur. Sanat; biçim ve içerik olarak sosyo-kültürel düşünce yapısıyla gelişmiş, din yardımıyla da somutlaştırılmıştır. Kapadokya bölgesinde yer alan ve Aksaray'ın bir ilçesi olan Güzelyurt, kendine has tarihi ve kültürel yapısının yanı sıra sivil ve dini mimari yapıları ile de ön plana çıkmaktadır. 1924 yılına kadar Güzelyurt'ta yaşamış olan Rum halkından geriye kalan, sivil ve dini mimari yapılarda görülen taş kabartmalar, din ve sanat ilişkisinin somut bir örneğini ortaya koymaktadır. Bu çalışmada, Güzelyurt'ta yerinde yapılan gözlem ve incelemeler sonucunda sivil ve dini mimari yapıların dış cephelerinde görülen bitki, hayvan ve kadın figürlü taş kabartma süslemelerin Hristiyanlık dini açısından taşıdığı önem ve dönemin sanat üslubu incelenmiştir. Ayrıca Güzelyurt'ta yaşamış ve halen yaşamakta olan halk ile birebir görüşmeler (mülakat) yapılmış olup halkın konu ile ilgili bilgi ve düşünceleri hakkında veriler toplanmıştır. Çalışmada; din ve sanatın etkileşimi sonucu sivil ve dini mimari yapılarda görülen taş kabartma süslemelerin yapım tekniği, şekli, kullanım amacı, anlamı, yeri ve dönemi hakkında temel bilgilerin edinilmesi amaçlanmıştır. Araştırmalar sonucunda dinin yaşama ait bir gerçeklik olması, sanatında bu gerçekliği estetik bir güzellik katıp somutlaştırarak yansıttığı görülmüştür. Ayrıca din ve sanat olgularının birbirinden büyük ölçüde etkilendiği ve bu iki olgunun gelişip yayıldığı gözlemlenmiştir. 


\begin{abstract}
The human beings' desire to regulate the place where they live and the environment due to the need for shelter and protection of human beings has begun with the action of architecture. Stone, which is the most basic shaping element of the architectural structure, has also been used as an ornamentation element and has been a tool for expressing feelings and thoughts by combining with religion, culture and aesthetic concerns. Architectural structures, which have entered the development process from the prehistoric times to the present day, have been affected by all kinds of social changes. Especially concepts such as religion and art played an important role in changing and developing architectural structures. Religion and art; although it may seem like two opposing concepts, it would be wrong to ignore the interaction between these two concepts. Art; it was developed with the socio-cultural thought structure as form and content. Guzelyurt is a district of Aksaray, located in the Cappadocia region, and stands out with its civil and religious architectural structures as well as its historical and cultural structure. The stone reliefs seen in the civil and religious architectural structures remaining from the Greek people who lived in Guzelyurt until 1924 reveal a concrete example of the relationship between religion and art. As a result of observations and examinations in Guzelyurt, the importance of Christianity in terms of Christianity and the style of art of the period were examined. In addition, oneto-one interviews were held with the people who lived and has still lived in Guzelyurt. Study; as a result of the interaction of religion and art, it is aimed to obtain the basic information about construction technique, shape, purpose, meaning, place and period of stone relief ornaments seen in civil and religious architectural structures. As a result of the researches, it is seen that religion is a reality of life and reflects this reality with its aesthetic beauty. Furthermore, it was observed that the cases of religion and art were greatly influenced by each other and these two phenomena developed and spread.
\end{abstract}

Keywords: Art, Religion, Guzelyurt, Stone Relief, Architecture

\title{
1. Giriș
}

İnsanoğlunun yerleşik hayata geçmesiyle birlikte ortaya çıkan din olgusu, beraberinde tanrı, kutsal kitaplar, ibadethaneler gibi birçok kavramın ortaya çıkmasına neden olmuştur. Bu kavramlar her alanda olduğu gibi hem sanat hem de mimari yapıların oluşum ve gelişim sürecinde etkileyici bir role sahip olmuştur. Her dinin kendine ait dini mekânları vardır ve bu mekânlar inançlar doğrultusunda birçok dini sembol ile süslenmiştir. Dini sembol; dini hatırlatan obje ya da göstergedir.

Tarihi süreç içerisinde insanoğlu, doğa başta olmak üzere, sayı, renk gibi unsurları mimari yapı ve benzeri ögelerde sembol olarak sıklıkla kullanmıştır. Sembolizmi kullanan insanoğlu, duygu ve düşüncelerini nesilden nesille aktarmayı başarmış ve metafizik hususların aktarımında da sembollerden yararlanmıştır (Has, 2005, s. 17). Din ile sanatın en önemli buluşma noktalarından biriside, sembollere verdikleri değer olarak açıklanmaktadır. Her iki alan da bireyin algısının değer kazanması noktasında, onun daha esnek bir tavır sergilemesine yardımcı olmaları bakımından zaman zaman sembolik anlatıma önem vermektedirler. Sanatta daha etkin olan sembolizm, dinde özellikle ibadetler açısından büyük bir değer taşımaktadır (Koç, 1995, s. 89). Bu hususta din ile sanatın benzeştikleri en önemli noktanın, her ikisinin de estetik olan boyuta vurgu yapmaları olduğu söylenmektedir (Has, 2005, s. 64).

Din ve sanat, mekânın el verdiği biçimde bir gelişim göstermiştir. Geçmişe baktığımızda ilkel insanların mağara duvarlarına yapmış olduğu resimler ile başlayan sanat, dinin gücü ile birleşerek 
sayısız eserlerin ortaya çıkmasına zemin hazırlamıştır. Dini konulardan da ilham alan sanat, her zaman duygu, düşünce ve hisleri bir başkasına iletmede en önemli ifade aracı olmuştur. Din ve sanat birbirinden etkilenmiş ve bu iki kavram kendi içlerinde bir gelişim göstermiştir. Din yaşama ait bir gerçeklik olarak görülürken, sanatta bu gerçekliğin bir yansıması olmuştur. İnsanoğlunun görmediği, tanımlayamadığı, dokunamadığı ama var olduğunu bildiği gerçekler vardır. İşte bu gerçekler sanat ile somutlaştırılmıştır.

Hristiyanlığın daha ilk y1llarında itibaren bir yerleşim yeri olan Kapadokya, M.S. 3. yüzyılda önemli bir dinî merkez halini almıştır. Günümüzde Niğde, Nevşehir, Kayseri ve Aksaray illeri arasında kalan bölge olarak adlandırılan Kapadokya'nın, gerçek coğrafi sınırları çok daha büyüktür (Olgunlu, 2016, s. 226). Aksaray ili, Kapadokya bölgesinde yer alan, kültür ve medeniyetler beşiği olan Anadolu'nun en eski yerleşim yerlerinden sadece birisidir. Stratejik önemi ve coğrafi konumundan dolayı tarih boyunca önemli bir misyona sahip olan il, tarih öncesi çağlardan itibaren birçok medeniyete ev sahipliği yapmış ve bu medeniyetlerin geride bırakmış olduğu tarihi zenginlikleri, farklı kültür ve inançların izlerini günümüze kadar getirmeyi başarmıştır.

Aksaray ili sınırları içinde yer alan; Pers, Hitit, Roma, Bizans, Selçuk ve Osmanlı gibi birçok medeniyete ev sahipliği yapan Güzelyurt; kültürel zenginliklerin uyum içinde olduğu nadide kentlerden birisidir. "Hristiyanlığın Kapadokya'da II. asırda yayılmaya başlaması" (Rodley, 1985, s. 213) sonucunda Güzelyurt önemli bir dini merkez haline gelmeye başlamış, bundan dolayı vasfina uygun hizmet amacı olarak farklı mimaride sayısız binalar inşa edilmiştir.

Hristiyan dünyasının önde gelen azizlerinden biri olan Aziz Gregorious Teologos önderliğinde Güzelyurt'ta Hristiyanlığın hızla yayılmasıyla (Mellaart, 1975, s. 92) Hristiyanlık inancını benimseyen halk İncil metinlerini, yorumları ve apokrif ${ }^{1}$ öyküleri okumaya başlamıştır. Bu metin, öykü ve yorumlarda yer alan olay, kişi ve nesneleri başta yaşadığı yerler olmak üzere birçok dini mekânları da duvar resmi, güzel yazı, taş oymacılığı gibi sanat dalları ile süsleme gereği duymuştur (Vassilis Zopoglou ile yapılan sözlü mülakattan, 17.09.2017). Böylece yörede yaşayan Hristiyan halk bu dinin metafizik öğretilerini ve dinin derinliğini sanat yardımı ile sembolleştirerek anlamaya ve anlamlandırmaya çalışmıştır.

Güzelyurt ilçesinde yarı kaya oyma yapıların yanı sıra çok sayıda kesme taş kullanılarak yapılmış olan yüksek kemerli sivil ve dini mimari yapıları görmek mümkündür. İlçede 59 adet sivil ve 19 adet dini mimari yapı kayıt altına alınmıştır. Güzelyurt'un toplumsal kimliğini ortaya koyan bu yapıların genellikle dış cephe duvarlarında yer alan bitki, hayvan ve kadın figürlü taş kabartma süslemeler mimari yapılara estetik bir değer katmıştır.

Çalışmada 10 adet sivil ve 1 adet dini mimari yapı incelemeye değer görülmüştür. Yerinde yapılan alan araştırması ve mübadele sonrası Yunanistan'ın Kavala şehrinde yaşayan Rum aileler ile görüşmeler yapılmıştır. Yapılarda taş kabartma ve elle şekillendirme tekniği kullanılarak ortaya çıkan hayvan, bitki ve kadın figürlü süslemelerin hangi amaçla mimari yapılarda kullanıldığ barındırdığı anlamlar açıklanmaya çalışılmıştır.

Din ve sanatın birleşmesiyle ortaya çıkan bu figürler mimari yapılarda farklı bir dilin ortaya çıkmasına sebep olmuştur. Ortaya çıkan bu dil, soyut değerlerin sanat aracılığı ile somut hale dönüştürülmesi sonucu dini kavramların daha kolay analiz edilmesine neden olmuştur. Bu çalışma ile kişi ya da belirli bir topluma özgü olan değerleri, inançları, sembolleri günümüze taşıyarak keşfedilmemiş yönlerini

\footnotetext{
1 Kutsal Yazi “Kanon” (Resmi liste) una kabul edilmeyen kitaplara “Apokrif” denir (Michel, 2012, s. 164).
} 
keşfetmek, geçmişte yaşamış olan toplumların dini inanışlarını ve sanat üsluplarını tanımak ve tanıtmak, din ve sanat arasında ki ilişkiyi anlamak açısından önem arz etmektir.

\section{Yöntem}

Araştırmada Betimsel Yöntem kullanılmıştır. Alan yazında literatür taraması yapılmış olup konu ile ilgili yazılı materyaller tek tek incelenerek analizi yapılmıştır. Bireysel yürütülen çalışmalar için sıklıkla tercih edilen örnek olay yöntemi ile sivil ve dini mimari yapılarda görülen insan, hayvan ve bitkisel figürlü taş süslemelerin, din ve sanat arasındaki etkileşimin bir sonucu olan somut yansımaları incelenmiştir. Araştırma konusuna kaynaklık eden Güzelyurt ilçesinde yerinde gözlem ve orada yaşamış ve halen yaşamakta olan halk ile yapılan birebir görüşmeler (mülakat) sayesinde halkın görüş, düşünce ve bilgileri araştırma konusuna kaynaklık etmiştir.

\section{Aksaray ve Güzelyurt Tarihçesi}

Aksaray ili Neolitik çağdan günümüze kadar farklı medeniyetlere ev sahipliği yapmıştır. Asur, Frig, Lidya, Medler, Pers, Kapadokya Krallığı, Roma, Bizans, Selçuklu Osmanlı gibi birçok uygarlığa kapılarını açan Aksaray, Anadolu'daki en eski yerleşim yeri olma özelliği göstermektedir (Anonim, 1982-83, s. 6235-6238). Kapadokya bölgesinde yer alan Aksaray; Ihlara Vadisi, İpek Yolu, Tuz Gölü, Hasan Dağı, antik kentleri, tarihi yapıları, yeraltı şehirleri, termal merkezleri ve kültürel zenginlikleri ile dikkat çeken ender şehirler arasında yer alır.

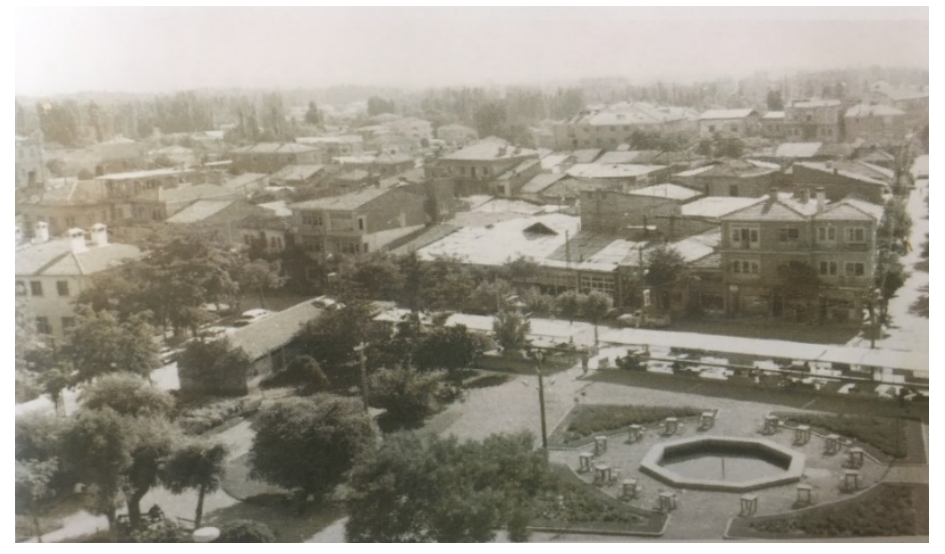

Fotoğraf 1. Aksaray ili genel görünüm

Aksaray ve çevresinin tarihi, çevresindeki höyüklerde yapılan kazılar ve buluntulara göre Neolitik Dönem'e kadar inmektedir (Anonim, 1982-8, s. 6173-6233). Antik Dönem'de "Garsaura" adıyla tanınan şehrin, M.Ö. 3000 yıllarında önemli Hitit merkezlerinden "Kursaura" ile aynı yer olduğu kabul edilmektedir. Son Kapadokya Kralı Archelaos tarafından yeniden kurularak krallığın başkenti yapıldıktan sonra "Archelais" adı ile anılmaya başlamıştır (Ramsay, 1897, s. 314). Kapadokya Kralı Archelaos şehre büyük önem vermiş ve geliştirmiştir. Şehrin Roma İmparatorluğuna geçmesinden sonra, Roma İmparatoru Cladius zamanında şehir Roma kolonisi olmuş ve adına "Colonia Archelais" denilmiştir (Şimşirgil, 2016, s. 169). Aksaray 1077 yılında Anadolu Selçuklu Devleti topraklarına katılmış ve II. İzzeddin Kılıç Arslan tarafından 1170'de saray, askeri meskenler, camiler, medreseler, hamamlar, zaviyeler, han ve çarşılar yaptırılarak yeniden kurulmuştur (Turan, 1984, s. 233).

Aksaray iline bağlı olan Güzelyurt, Kapadokya bölgesinin güneybatısında, Hasan Dağı'nın kuzeydoğusunda yer almaktadır. Yapılan araştırmalar yörenin, prehistorik devirlerden bu yana bir yerleşim yeri olduğunu göstermektedir. 
Güzelyurt'un 1.5 km kadar güneybatısında, Hagios Analipheos Manastırı'nın yakınındaki Gelveri Höyüğünde yapılan kazı çalışmaları sırasında, yüzeyden toplanan sırsız seramik parçalarına göre höyükte Roma, Demir Çağı, İlk Tunç Çağı ve Kalkolitik yerleşimlerin var olduğu anlaşılmaktadır. Ayrıca; Hitit, Lidya ve Pers gibi birçok kültüre de ev sahipliği yapmıştır (Esin, 1993, s. 47-56).

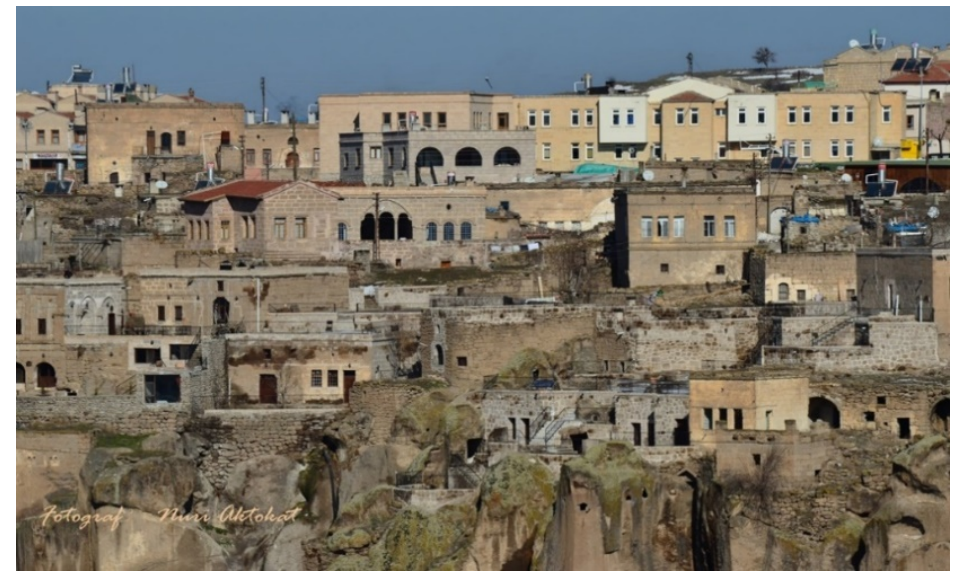

Fotoğraf 2. Güzelyurt ilçesi görünüm

Roma İmparatorluğu'nun ikiye ayrılmasından sonra bölge, Bizans toprakları içinde kalmıştır (Foss, 1991, s. 378). Bu dönemde, Aziz Gregorios Theologos'un mektuplarından Güzelyurt'un Karbala adında Hıristiyanların yaşadığı küçük bir köy olduğu anlaşılmaktadır (Ramsay, 1897, s. 245). "Karballa" adının Roma ve erken Hıristiyanlık dönemlerinde de kullanıldığını, "B" harfinin zamanla "V" haline dönüşerek "Karvala" gibi okunduğu belirtilmektedir. Ayrıca; Güzelyurt'un Anadolu Selçukluları zamanında "Gerfeli" olarak bilindiği, Kanuni Sultan Süleyman devri kayıtlarında ise “Korveli” şeklinde yazıldığı aktarılmıştır (Konyalı, 1975, s. 1944).

Güzelyurt, önce Anadolu Selçuklularının hâkimiyetine, ardından Moğol idaresi altında Eretna Beyliği'ne katılmıştır. Daha sonra Karamanoğulları topraklarına dâhil olmuş ve son olarak Fatih Sultan Mehmet tarafindan fethedilerek Osmanlı toprağı haline gelmiştir. Osmanlı toprağına katılan Güzelyurt'ta hem Rum hem de Müslüman halk, 1924'te gerçekleşen mübadele dönemine kadar hoşgörü içinde birlikte yaşamışlardır (Kaya, 2009, s. 4).

\section{Güzelyurt Mimari Yapılarında Görülen Taş Kabartma Süslemeler}

İnsanoğlunun temel ihtiyaçlarından biri olan ve barınma ile birlikte ortaya çıkan mimari yapılar, kültürel mirasın bir kanıtı olarak günümüze kadar varlıklarını sürdürmüşlerdir. Bu yapılar, toplumun kendine ait tarihi, kültürel değerleri, dini inançları ve sanat üslupları hakkında bilgiler vermektedir. Tarih boyunca önemli uygarlıklara ev sahipliği yapmış olan Güzelyurt, birçok dinin uğrak yeri olmuş ve farklı inançlara sahip insan topluluklarının yaşadığı bir yer olma özelliği göstermiştir. 


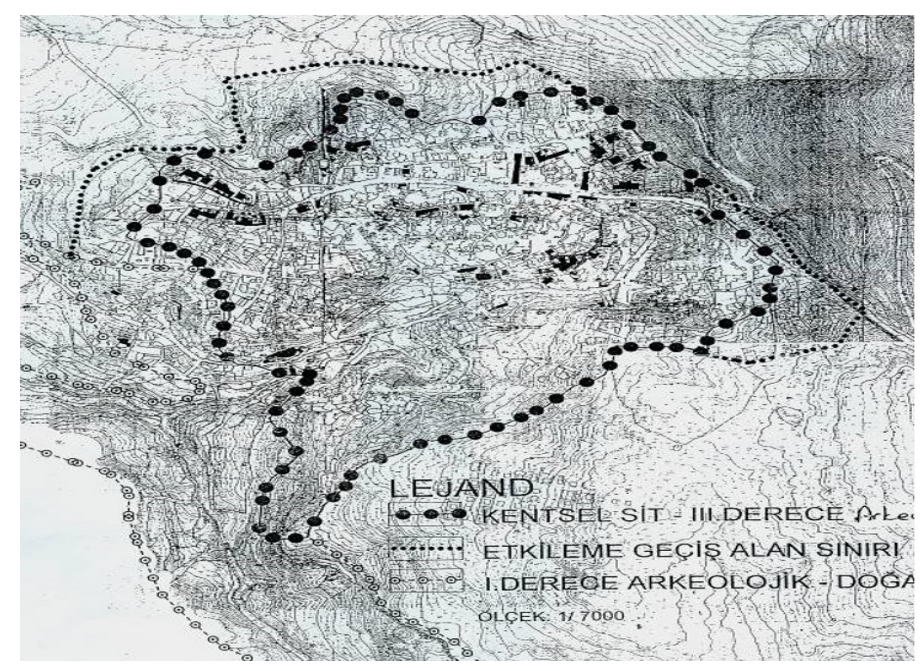

Fotoğraf 3. Güzelyurt ilçesi sit alanları paftası

Üç büyük dinden biri olan Hristiyanlık inancının burada yayılmaya başlamasıyla, bu dine ait olan soyut kavramların taş kabartma tekniğiyle somutlaştırılarak sivil ve dini mimari yapılarda yer aldığ gözlenmiştir. Bu mimari yapıların temel elemanı olarak kullanılan andezit ve ignimbrit gibi volkanik kökenli taşlar, dönemin taş ustaları sayesinde şekillendirilmekteydi. Taş ustaları yüzeyi taşçı keskileri ile düzeltip, taşçı kalemleri başta olmak üzere çekiç, keser, tokmak gibi saplı aletler kullanarak istenilen duygu ve düşünceleri taşlara yansıtmayı başarmıştır. Sivil ve dini mimari yapılarda görülen taş kabartma süslemeler; hayvan, bitki ve insan figürlü olmak üzere üç grupta incelenmiştir.

\subsection{Hayvan Figürlü Taș Kabartma Süslemeler}

\subsubsection{Aslan}

Aslan figürü, Hristiyan sembolizminde soyut fikirleri ve kavramları temsil etmek için kullanılan dini bir semboldür (Horvart, t.y.). Hıristiyanların kutsal kitaplarında sık sık anlatılan dört hayvandan biri olan aslan hem Mesih'in hem de kurtuluşun sembolü olarak bilinmektedir. Evangelistlerden biri olan Aziz Marcus aslanla sembolize edilir. Aslan ayrıca İsa'nın dirilişini temsil eder ve Hristiyanların kurtuluş yolunda cesur olması gerektiğini ifade eder. İncil'de yer alan aslan figürü kilise portallarında, apsis ve buna benzer pek çok yerde tasvir edilmiştir (Veith, 2009).

Güzelyurt’ta sivil ve dini mimari yapılarda oldukça sık görülen aslan figürü elle şekillendirme ve taş kabartma olmak üzere iki farklı teknikte karşımıza çıkmaktadır. 1900 yılında yapılan ve halen Aksaray Üniversitesi Güzelyurt M.Y.O. binası olarak kullanılan yapının, üçlü beşik çatı kısmında çatı birleşim yerlerinde yer alan aslan başı figürü, kırmızı çamurdan elle şekillendirme tekniği kullanılarak yapılmıştır. Bina çatısının batı yönüne bakan tarafta bulunan aslan figürü iki ön ayağının üstünde ağzı yarım açık, dişleri ve dili net bir şekilde tasvir edilmiştir. Çizgisel süslemelerin kullanılarak aslan yelesi görünümü verilen figürün detaylı bir şekilde tasvir edildiği görülmektedir (Fotoğraf 4-5). 


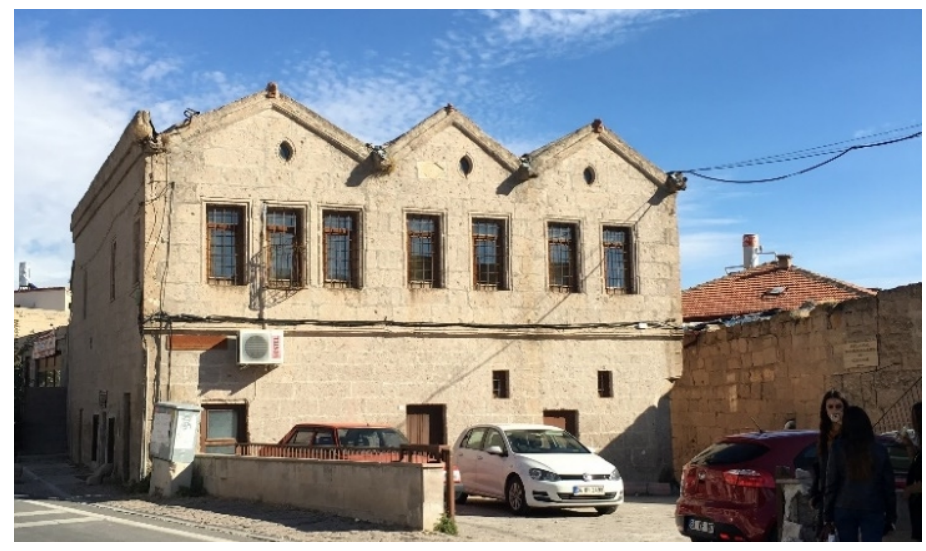

Fotoğraf 4. Aksaray Üniversitesi Güzelyurt M.Y.O. binası olarak kullanılan sivil mimari yapı
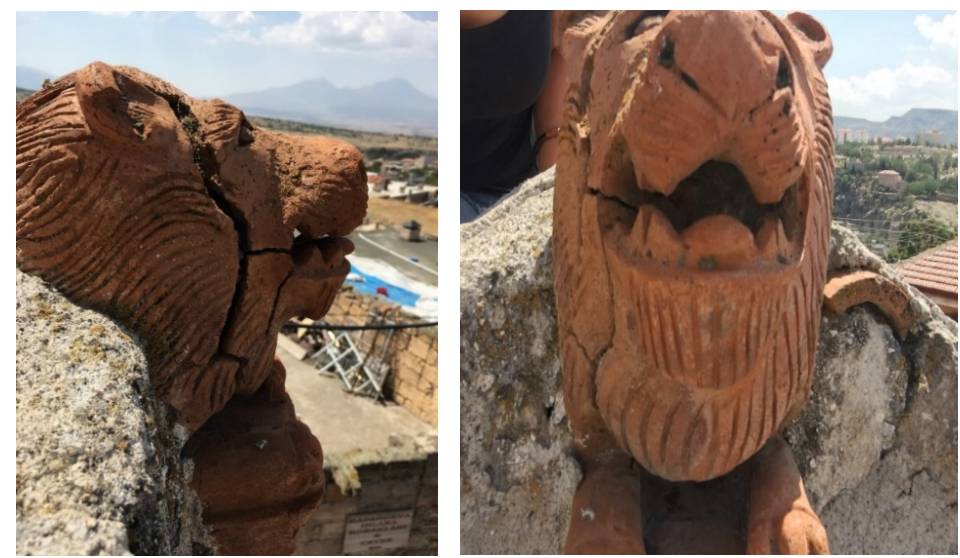

Fotoğraf 5. Sivil mimari yapıda görülen, elle şekillendirme yöntemi ile yapılmış aslan başı figürü

Kesme taştan yapılmış sivil bir yapıda görülen ve kesme taşla birlikte oyularak yapılan aslan figürü, Veysel Dik'e ait olan evin giriş kapısının üst kısmında yer almaktadır. Sol bacağı havada duran figürde belirleyici özellik aslanın yelesi ve kuyruğudur. Yüzü ise bir aslan tasvirinden uzak görünmektedir. Yaklaşı $50 x 25 \mathrm{~cm}$ boyutlarında olan aslan figürünün önceden göz kısmında mavi cam boncuk bulunduğunun fakat değerli bir taş zannedilip söküldüğü söylenmiştir (Veysel Dik ile yapılan mülakattan, 17.08.2017).
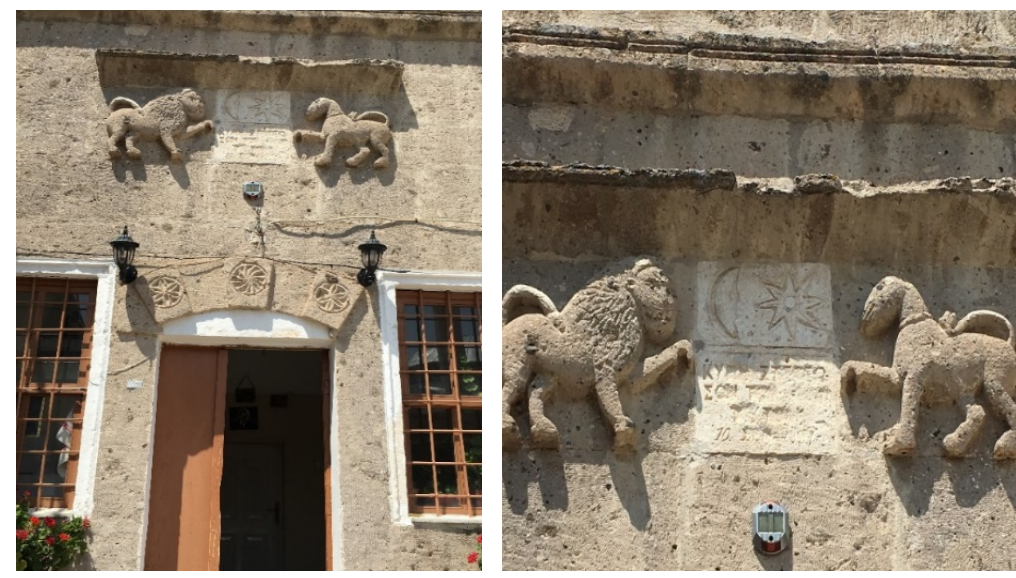

Fotoğraf 6. Veysel Dik'e ait olan evin giriş kapısının üst kısmında solda yer alan aslan figürü 


\subsubsection{Güvercin}

Hristiyan sanatı ve ikonografisinde güvercinin ilahi bir yönü temsil ettiği, ruhların barışı ve mutluluğun sembolü olduğu bilinmektedir. Güvercin; fiziki bir barıştan ziyade ruhun barışını temsil etmektedir (Snyder, 2003, s. 263).

Sivil mimaride göremediğimiz güvercin figürü Manastır vadisi içinde Cevizli Sokakta yer alan, Güzelyurt'un büyük ve önemli bir dini yapısı olan Kilise Cami'nin giriş kapısının sağ ve sol kısmında bulunan yarım sütunlarda görülmektedir.
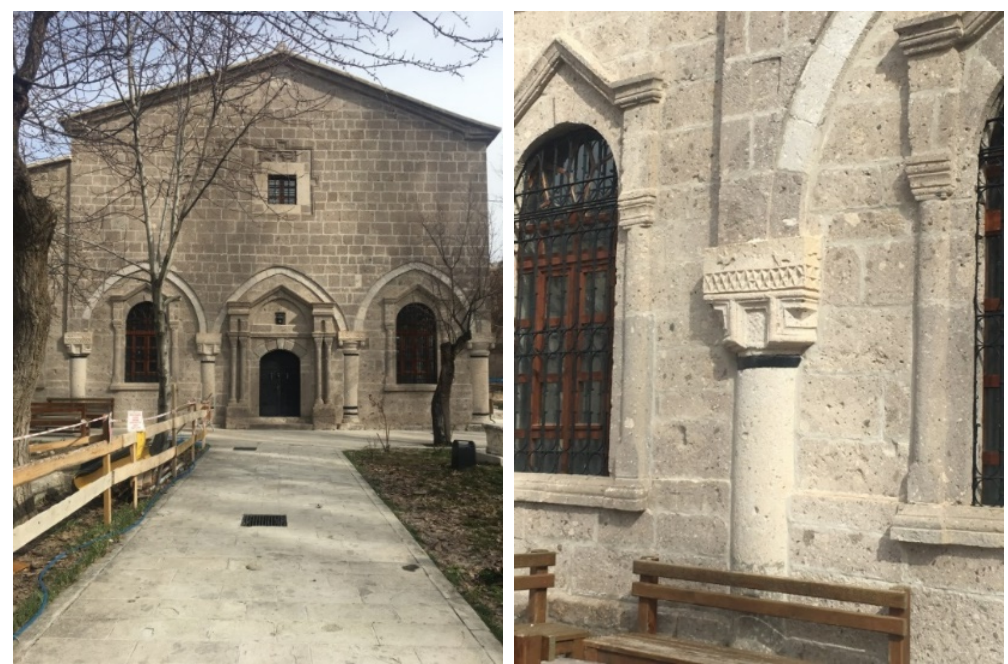

Fotoğraf 7. Kilise Cami giriş kapısında yer alan yarım sütunlarda görülen güvercin figürü.

Taş kabartma tekniği (rölyef) kullanılarak yapılan güvercin figürü uçarken, fazla detaya girilmeden basit bir şekilde tasvir edilmiştir. Figürün hemen altında yer alan içleri oyulmuş baklava şeklinde ki bordür güvercin figürünü süsleme açısından tamamlamıştır.

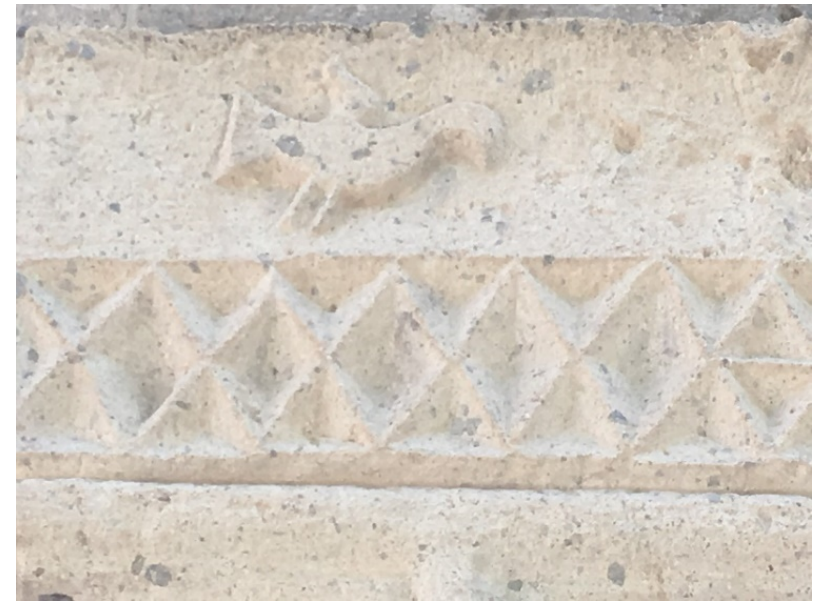

Fotoğraf 8. Kilise Camii girişinde yer alan yarım sütunlarda görülen güvercin figürü detay.

\subsubsection{Boğa}

Boğa gücü, hizmeti, alçak gönüllüğü ve sabrı simgelemektedir. Boğa hem Hıristiyanlığın hem de Yahudiliğin dini metinlerinde ve şarkılarında sıklıkla görülür ve Evangelistlerden Aziz Luke’u simgelemektedir. Kurban, hizmet ve güç olarak bilinen boğa, Hristiyanların Mesih’i takip ederek kendini feda etmeye hazır olduklarını göstermektedir (Horvart, t.y.). 


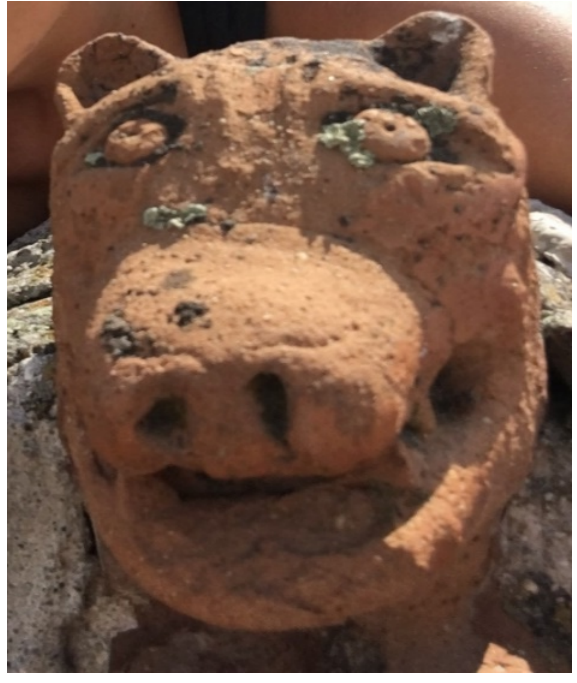

Fotoğraf 9. Elle şekillendirme yöntemi ile yapılmış boğa figürü

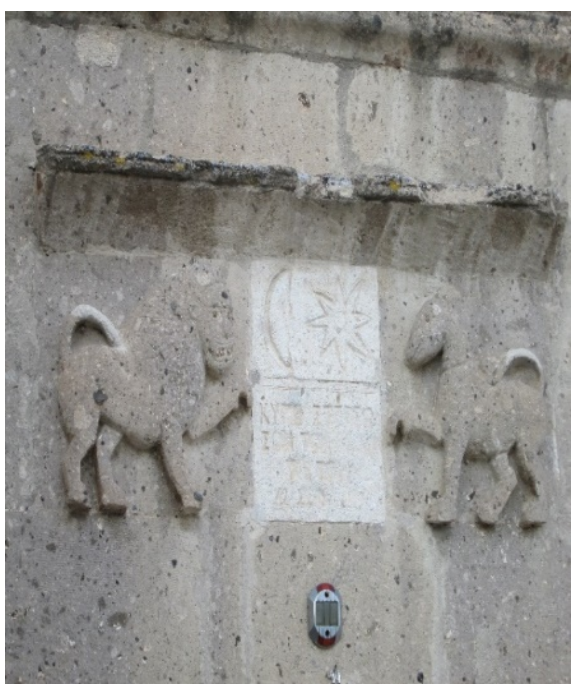

Fotoğraf 10. Veysel Dik'in evinde yer alan karşıllklı boğa ve aslan figürü

Sivil ve dini mimari yapılarda görülen boğa figürü, taş kabartma ve elle şekillendirme olmak üzere iki şekilde karşımıza çıkmaktadır. 1900 yılında yapılan ve halen Aksaray Üniversitesi Güzelyurt M.Y.O. binası olarak kullanılan evin çatısının uç kısımlarında görülen boğa figürü, yine aslan figürü ile birlikte görülmektedir. Kırmızı çamurdan elle şekillendirme tekniği kullanılarak yapılan figür, ağzı yarım açık, dişleri, kulak ve gözleri belirgin bir biçimde tasvir edilmiştir (Fotoğraf 9-10). Veysel Dik’e ait olan evde görülen boğa figürü, taş kabartma tekniği kullanılarak $50 \times 20 \mathrm{~cm}$ boyutlarında yapılmıştır. Sağ ayağı havada, boynuz ve kulaklara sahip olmayan figür, ilk bakışta gerçek bir boğa figüründen oldukça farklı görünmektedir. Sivil ve dini mimari yapılarda aslan ve boğa figürü her daim karşılıklı ya da yan yana tasvir edilmiştir. 


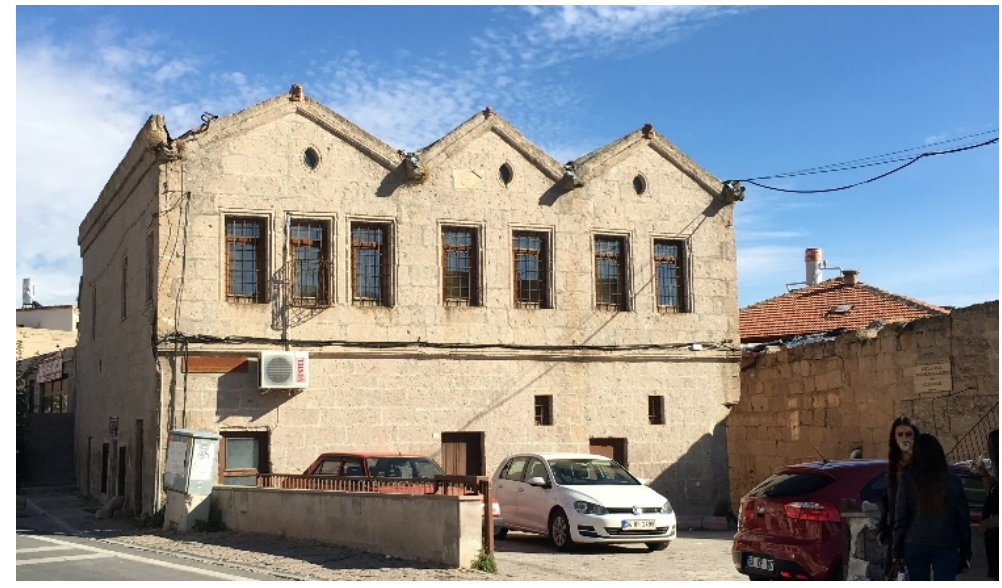

Fotoğraf 11. Aksaray Üniversitesi Güzelyurt M.Y.O. binası

İncil'de sıklıkla yer alan bu canlıların belirtilen özellikleri nedeniyle birbirleri ile bağlantılı olduğunu, aslanın; üstün gücü, kudreti ve adaleti, boğanın; alçak gönüllülüğü ve hizmeti simgelediğini söylemiştir. Sivil ve dini mimari yapılarda görülen, bitki ve hayvan figürlü süslemelerin birçoğunun Hristiyanların kutsal kitabı İncil'de yer alan metin, öykü ve yorumlarda bahsedilen kişi ve nesnelerin birer yansıması olduğunu ifade etmiştir (Vassilis Zopoglou ile yapılan görüşmeden, 17.09.2017).

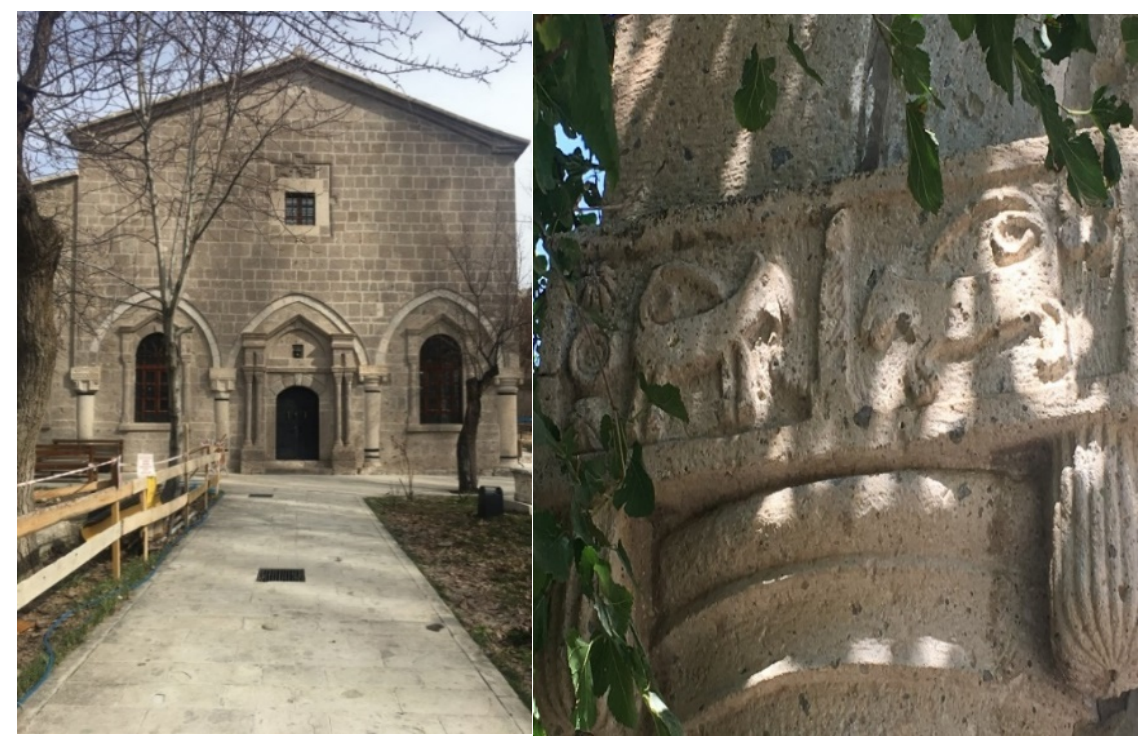

Fotoğraf 12. Kilise Cami 'nin giriş yarım sütununda yer alan taş kabartma aslan ve boğa figürü

\subsection{Kadın Figürlü Taş Kabartma Süslemeler}

\subsubsection{Gelveri Gelini -Tanrıça Tanit}

Tanrıça Tanit, Batı Akdeniz'den Malta'ya hatta Helenistik dönemlere kadar ibadet edilen bir tanrıçadır (Smith ve Gal, 2014, s. 338). Güneş, ay ve yıldıza hâkim olduğu düşünülen ve "Gökyüzü Tanrıçası" olarak isimlendirilen Tanit tasvirinin doğurganlığı temsil ettiği söylenmektedir (Cintas, 1948, s. 234). 


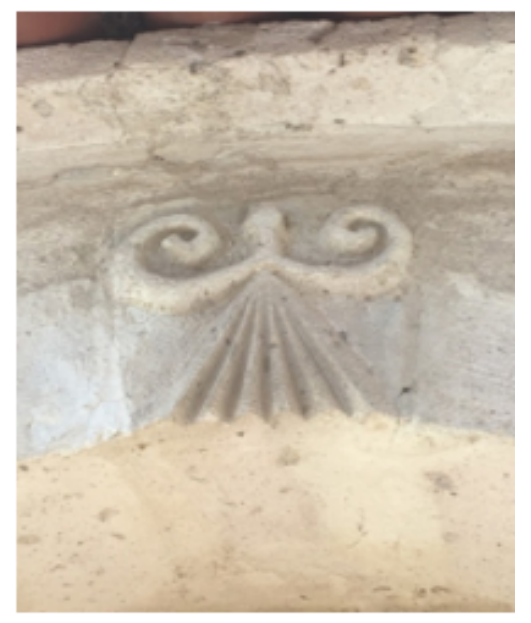

Fotoğraf 13. Gelveri gelini olarak bilinen kadın figürü.

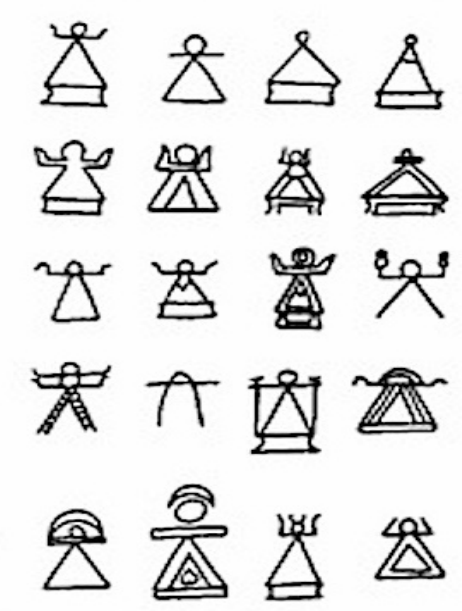

Fotoğraf 14. Tanrıça Tanit'in Kartaca'da ki farklı tasvirleri.

Sadece sivil mimari yapıların giriş kapısının kilit taşı üstünde ya da pencerelerin üst kısmında yer alan taş kabartma figür detaylı olarak incelendiğinde; elips ya da oval bir baş ile tasvir edilmiştir, ellerini gökyüzüne kaldırmış dua eden bir kadın olarak yorumlanabilir. Vücut üçgen şeklinde olup pile görünümü verilmiş bir elbiseyi andırmaktadır. Kollar iki yana doğru uzanan, içe doğru kıvrılmış spiral şekilde tasvir edilmiştir (Uray ve Gümüş, 2017, s. 525).
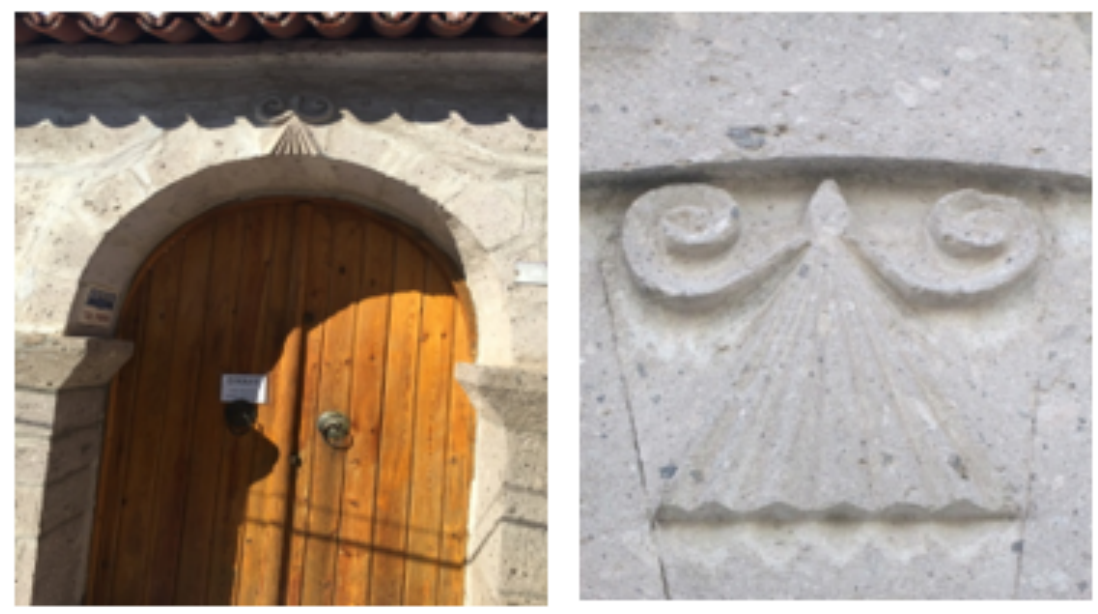

Fotoğraf 15. Sivil mimari yapılarında görülen Tanrıça Tanit figürü 
Güzelyurt'ta yaşayan Alman araştırmacı-yazar Udo Hirsc ile yapılan görüşmede, bu figürün koruyucu bir tanrıça figürü olduğunu, doğum yapan kadınların bebeklerini kötülüklerden korumak için evlerinin giriş kapısına ya da pencere üstlerine bu figürü yaptırdıklarını belirtmiştir. Ayrıca hasta doğan bebeklerin ya da hastalanan çocukların şifa bulmasını isteyen ailelerin tanrıça figürünün şifa veren ve koruyucu bir gücü olduğuna inandıklarını söylemiştir (Udo Hirsc ile 02.01.2017 tarihinde yapılan görüşmeden, Güzelyurt).
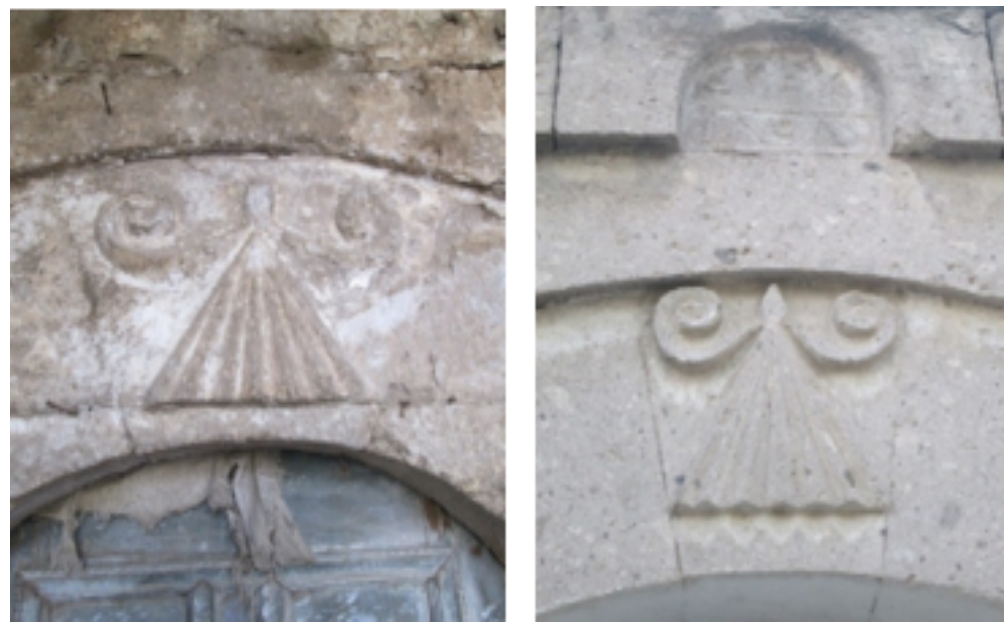

Fotoğraf 16. Sivil mimari yapılarda görülen Tanrıça Tanit figürü

\subsection{Bitkisel Figürlü Taş Kabartma Süslemeler}

\subsection{1. Çarkıfelek- Papatya Tekeri}

Güzelyurt'ta çarkıfelek ya da çiçek motifi olarak bilinen daha çok sivil ve dini mimari yapılarda karşımıza çıkan figür, Hristiyan inancında sıklıkla kullanılan "Papatya Tekeri” figürüdür. "Papatya Tekeri” Hristiyan inancında, cadı işareti, altıgen pusula, apotropik (kötülüğe karşı koruyucu) bir sembol olduğu bilinmektedir (Uray ve Gümüş, 2017, s. 216-220). Güneşi temsil etmesinden dolay1 bazı tarihçiler ve din adamları arasında kötülüğe karşı koruyucu ve engelleyici olduğu da düşünülmektedir. Genellikle savunması olduğu düşünülen kap1 girişlerinde görülen bu sembol, kötülüğe karşı bir savunma olarak görülmektedir (Emerson, 2014, s. 161).
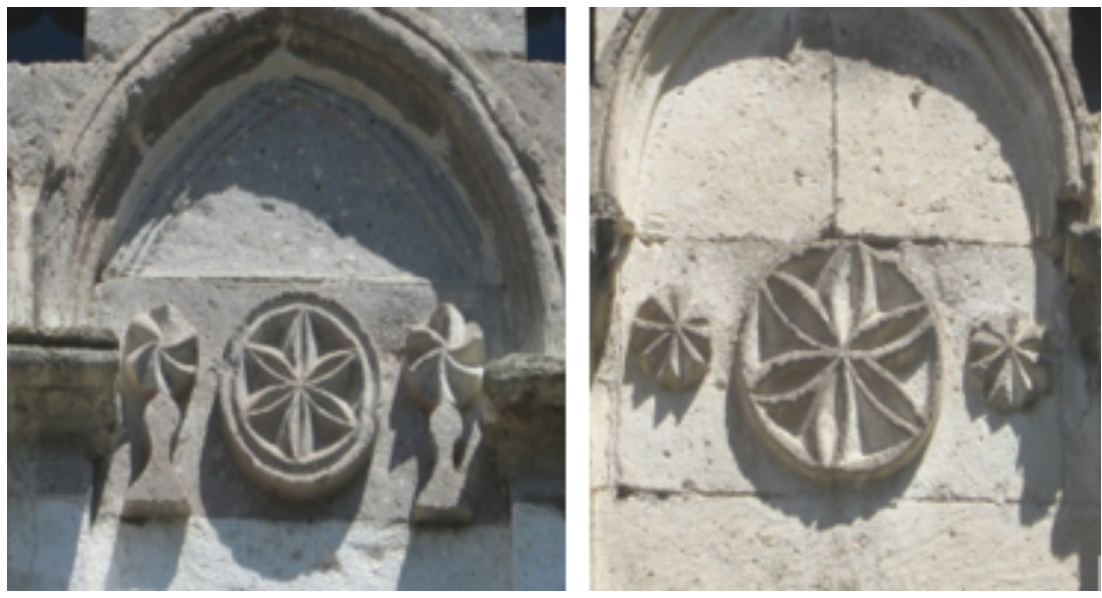

Fotoğraf 17. Çarkıfelek- Papatya tekeri figürü detay görünüm 
Kesme taş üstüne kabartma tekniği ile yapılan figür, altı taç yapraklı çift ya da tek şeritli daire içine oyularak yükseltme suretiyle kabartılmıştır. Figür bazen sağ ve sol tarafinda küçük bir ağacı andıran şekille birlikte tasvir edilirken bazen de parçalara bölünmüş iki küçük daire ile tasvir edilmiştir (Fotoğraf 20).

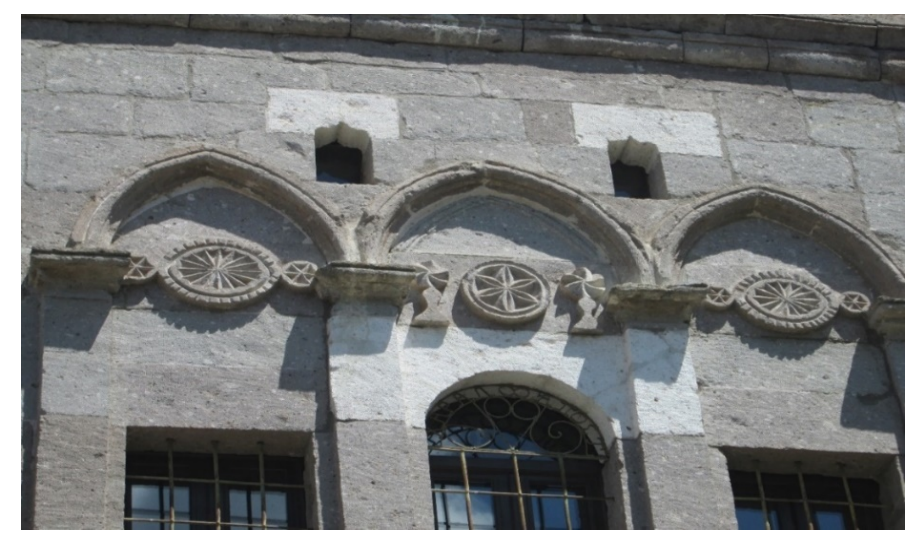

Fotoğraf 18. Sivil mimari yapıda görülen Papatya tekeri figürü

\subsubsection{Zeytin Ağacı - Asher'in Sembolü}

İbranice mutlu, mesut ve nimet anlamına gelen "Asher" Hz. Yakup'un sekizinci oğludur. Asher ve kabilesi bolluk ve bereket içinde yaşayan, sahip olduklarını paylaşan biri olarak kabul görmüştür. Kutsal kitaplarda zeytin ağacı ile sembolize edilen Asher, zengin çayırların sahibi olarak bilinmektedir (Orr, 1915, s. 227-457).

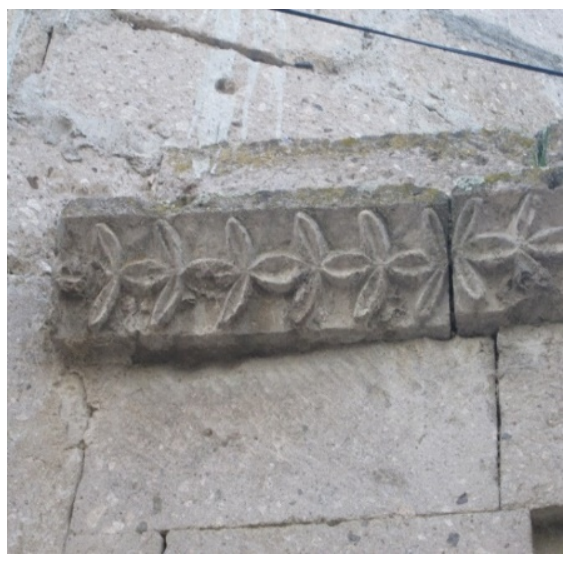

Fotoğraf 19. Sivil mimari yapının dış cephe duvarında görülen zeytin yaprakları tasviri

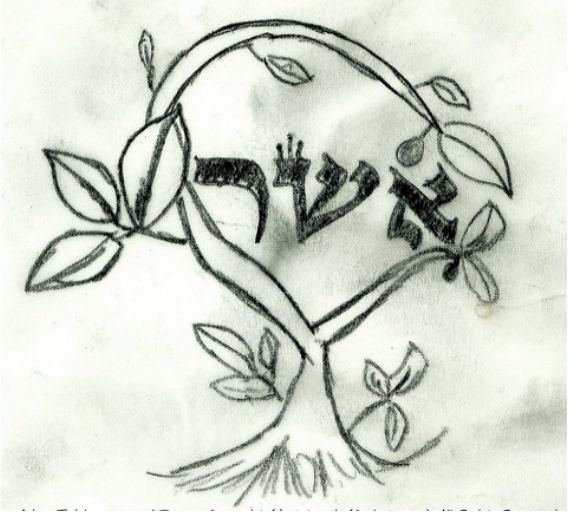

Fotoğraf 20. Asher'ı temsil eden zeytin yaprakları 
Güzelyurt sivil mimari yapıların kapı girişlerinin üstleri, dış cephe duvarları ve pencere kenarlarında görülen taş kabartma farklı şekiller ile birleştirilerek bir kompozisyon oluşturmuştur. Yüzey üzerinin yükseltilmesiyle yapılan figür, kapı girişi ya da dış cephe duvarlarını tamamen kaplayacak dar ve uzun bir şekilde yapılmıştır.

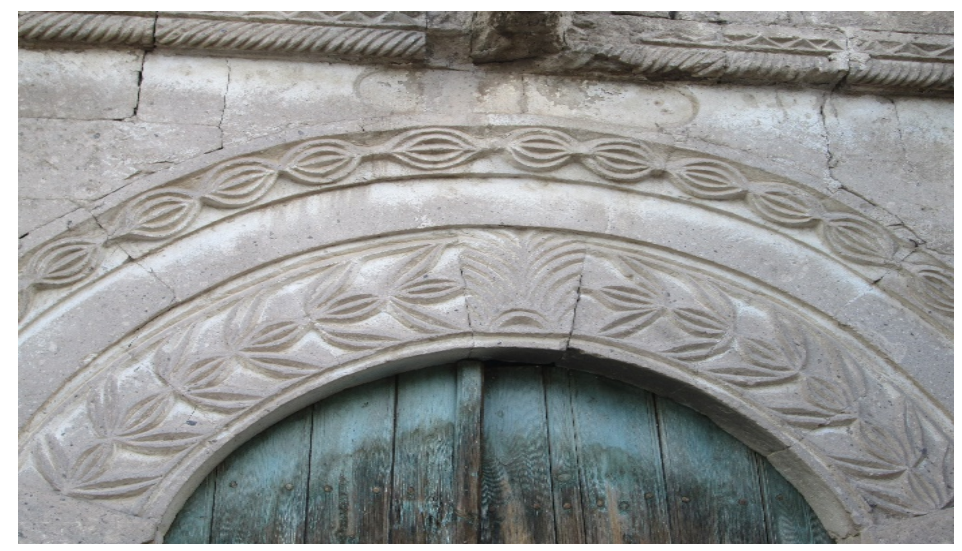

Fotoğraf 21. Sivil mimari yapının giriş kapısının üstünde yer alan zeytin yaprakları

\subsubsection{Hayat Ağacı- Palmiye Yaprakları}

Hristiyan inancında palmiye ağacı yapraklarının tasvir edildiği evlerin, şehit vermiş bir hane olduğunu belirtmek için kullanıldığı bilinmektedir. İlk Hristiyanlar tarafından kabul edilen ve ruhun düşmanlar üzerinde sadık zaferin bir sembolü olarak bilinen palmiye dalları, aynı zamanda iyi şans vermesi ve mahsullerin koruması için evlerde sıklıkla kullanılmaktadır (Hasset, 1911, s. 749). Güzelyurt'ta buğday ya da hayat ağacı olarak bilinen figür, mimari yapıların dış cephe duvarlarında taş konsollarla çıkma yapıldığ1 görülmektedir. Yüzey üzerinin yükseltilmesiyle yapılan palmiye figürü, farklı şekillerin bir araya getirilmesi ile bütünlük sağlanmıştır.

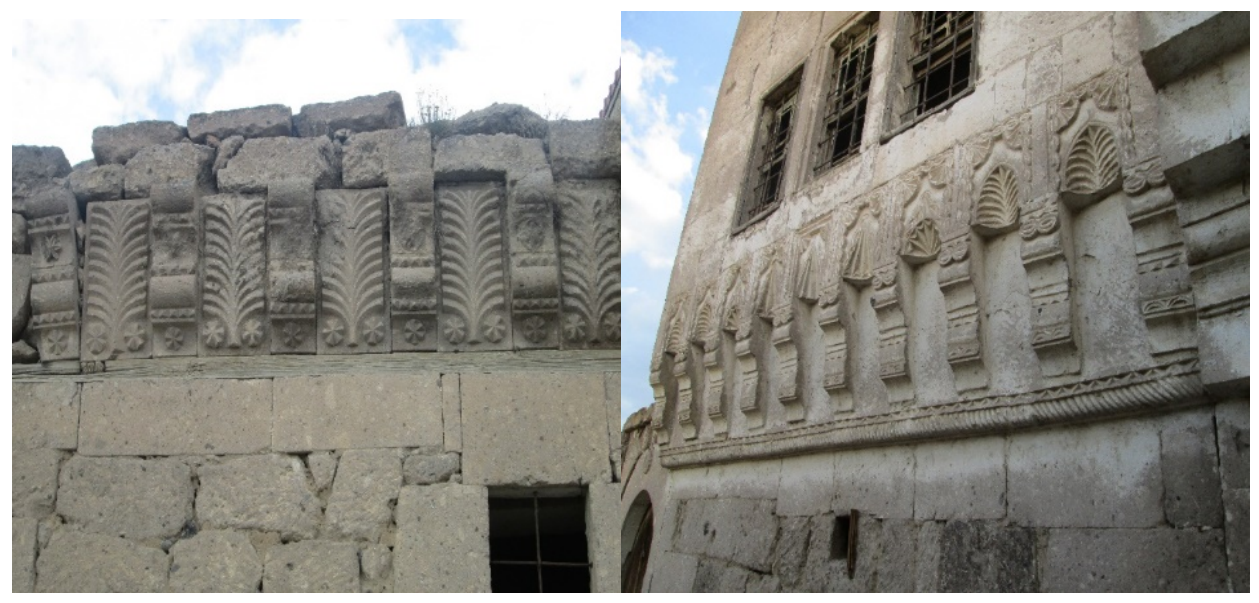

Fotoğraf 22. Sivil mimari yapının dış cephe duvarlarında yer alan palmiye figürü

\section{Sonuç}

Sanat insanoğlunun var oluş hikâyesiyle birlikte ortaya çıkmış ve insanoğlu yaşamına ait bütün değerleri farklı bir şekilde sanata yansımıştır. Bu değerlerin başında gelen din olgusunun sanatla sıkı bir ilişkisi bulunmaktadır. Din ve sanat arasındaki ilişkinin sebeplerinden biri, sanatın dini değerleri anlatmada daha etkili olmasıdır. Geçmişten günümüze kadar yaşamış olan toplumların sanat anlayışlarında dinsel eğilimlerin önemli bir etkisi olduğu görülmektedir. Sanat; İslamiyet, Hristiyanlık, Yahudilik gibi dinlerin metafizik dünyasından esinlenerek gelişimini sürdürmeye devam ettirmiştir. 
Üç büyük dinden biri olan Hristiyanlık inancının dinsel ideolojisi, sanatın her alanına yansıyarak farklı bir estetik anlayışın doğmasına neden olmuştur. Bu dine inanan topluluklar Hz. İsa ve Hz. Meryem başta olmak üzere kutsal kitapları İncil'de yer alan öykü, olay, kişi ve nesneleri sembolleştirerek daha kolay anlaşılmasını sağlamıştır. Kutsal ögeleri içinde barındıran din, bunları dışa vurmak ve somutlaştırmak için sanatı tercih etmiştir. Tarihe baktığımızda insanoğlunun hayatında din ve sembolizm önemli bir rol oynamıştır. Yaratıcıyı hatırlatan birtakım nesneleri sembol olarak kabul eden insanoğlu, inançlarını dini semboller aracılığı ile somutlaştırma yoluna gitmiş ve kendinin maddimanevi yönden korunduğunu düşünmüştür.

Aksaray ve ilçelerinde yapılan alan araştırması sonucu bitki, hayvan ve kadın figürlü taş kabartma süslemelerin sadece Güzelyurt'ta yer alması dikkat çekici özelliktedir. Kapsamlı literatür taraması, alan araştırması ve kaynak kişiler ile yapılan görüşmeler araştırma konusuna kaynaklık etmektedir. Ayrıca daha önce ilçede yaşamış olan fakat mübadele sonucu Yunanistan'ın Kavala şehrine göç etmiş olan aileler ile de görüşmeler yapılmıştır. Güzelyurt'ta envantere 78 adet tarihi taş kemerli mimari yapı kayıtlıdır. Bunların 19 adetini dini, 59 adetini ise sivil mimari yapılar oluşturmaktadır (Ayçin, Salman, Yeğen, Ulu Kurtaran, Karaköy ve Ok, 2010, s. 6-7). Araştırma kapsamına giren 10 sivil ve 1 dini mimari yapı incelemeye değer görülmüştür. Kesme taş duvarlardan yapılmış olan kilise ve evlerin dış cephe duvarlarında görülen taş kabartma süslemeler, dönem insanının dini inançları, estetik kaygıları ve sanat üslupları hakkında bilgiler vermektedir. Yörede "Gelveri gelini" olarak bilinen figürün sadece sivil mimari yapılarda yer alması, aslan ve boğa figürünün karşılıklı ya da yan yana tasvirinin dışında başka şekilde karşımıza çıkmaması, bu figürlerin koruyuculuğuna ve gücüne inanılması elde edilen bilgilerdir. Döneme ait taş işçiliğinin en güzel örnekleri dış cephe duvarları, avlu, çatı, giriş kapısı ve pencere üstlerinde görülmektedir. Ayrıca süslemede kullanılan hayvan, bitki ve kadın figürlü ögelerin Hristiyan inancındaki yeri ve önemi elde edilen diğer bilgilerdir. Yüzey üzerinin yükseltilerek yapılan kabartmaların dışında kırmızı çamur kullanarak elle şekillendirme tekniğinin kullanıldığı figürler tespit edilmiştir.

Güzelyurt'ta sivil ve dini mimari yapılarda görülen taş kabartma süslemeleri basit bir şekil olarak değerlendirmek yanlış olur. $\mathrm{O}$ dönemde yaşamış olan insanların ruhsal dünyalarını, din ve estetik değerleriyle birleştirerek kişi, nesne ya da olaylara işlevsellik bir anlam, bir mana kazandırmak olarak bakılmalıdır.

Din yaşama ait var olan şeylerin tümüdür, sanat ise bu gerçekliğin somut bir yansımasıdır. Bu nedenle din ve sanatın birbirini besleyerek ortaya çıkarttığı sivil ve dini mimari yapıları sadece tarihi bir yap1 olarak görmemeli ait olduğu dönem içinde değerlendirilerek, din, sanat ve kültürel açıdan detaylı olarak incelenmesi gerekmektedir. Böylece ülkemizde yaşamış olan uygarlıkların inançları, kültürleri, sanat üslupları hakkında daha çok bilgi edinmemizi sağlayarak, bu bilgileri gelecek kuşaklara aktarmak açısından önem arz etmektedir.

\section{Kaynakça}

Anonim. (1982). Aksaray maddesi. Yurt Ansiklopedisi. İstanbul: Anadolu Yayıncılık.

Ayçin, F., Salman, Ş., Yeğen, A., Ulu Kurtaran, A., Karaköy, G., Ok, Ö. (2010). Kültür envanteri (Aksaray-Güzelyurt-1). Aksaray: Aksaray Valiliği İl Kültür ve Turizm Müdürlüğü.

Cintas, P. (1948). Un sanctuaire pre-carthaginois sur la greve de Salammbo Revue Tunuian: Tunisienne Publie Par L'Insttut De Carthage.

Emerson, B. (2014). A storm of witchcraft the Salem trials and AmericaneExperience. England: Oxford University Press. 
Esin, U. (1993). Gelveri-Ein Beispiel für die kulturellen Beziehungen zwischen Zentralanatolien und Südosteuropa während des Chalkolithikums Anatolica. Netherlands: Netherlands Institute.

Foss, C. (1991). Cappadocia, The Oxford Dictionary of Byzantium, Volume 1. England: Oxford University.

Has, K. (2005). Sembolizm ve haç. Ankara: İlahiyat Yayınları.

Hasset, M. (1911). Palm in Christian symbolism, The Catholic Encyclopedia, Vol. 11. New York: Robert Appleton Company.

Horvart, M. T. (t.y.). The man, the ox, the lion and the eagle [Blog yazıs1]. Erişim adresi: http://www. traditioninaction.org/religious/f005rp.htm

Kaya, E. (2009). On bin yillık tarihi kent Aksaray. Aksaray: Yeni Aksaray Basın Yayın.

Koç, T. (1995). Din dili. Kayseri: Rey Yayıncılık.

Konyalı, İ. H. (1975). Abideleri ve kitabeleri ile Niğde Aksaray tarihi C.1- 2: İstanbul: Fatih Yayınevi Matbaas1.

Mellaart, J. (1975). The Neolithic of the Near East. London: The American Schools of Oriental Research.

Michel T. (2012). Hristiyan Tanrı bilimine giriş. İstanbul: Sak Ofset Reklamcılık Yayıncıllk Matbaac1lik.

Orr, J. (2015). Entry of lion, International Standard Bible Encyclopedia. Unidet States: Delmarva Publication.

Ramsay, W. M. (1897). Impressions of Turkey during twelve years wanderings. London: Library of the Univercity of California.

Rodley, L. (1985). Cave monasteries of Byzantine Cappadocia. United Kingdom: Cambridge Unıversity Press.

Smith, P., Gal, A. (2014). Age estimations attestto infant sacrifice at the Carthage Tophet. London: Cambridge University Press.

Snyder, D. G. (2003). Ante pacem, archaeological evidence of church life before Constantine. USA: Mercer University Press.

Şimşirgil, A. (2016). Sultan II. Kıllı̧ Arslan ve Aksaray. İstanbul: IQ Kültür Sanat Yayıncılık.

Turan, O. (1984). Oniki Hayvanlı Türk Takvimi. İstanbul: Cumhuriyet Matbaas1.

Uray, G. ve Gümüş, D. (2017). Aksaray ili Güzelyurt ilçesinde Tanrıça Tanit'in izleri. Turkish Studies, 12 (21), 519-530. doi: http://dx.doi.org/10.7827/TurkishStudies.12207

Uray, G. ve Gümüş, D. (2017, 29 Nisan-1 Mayıs). Aksaray ili Güzelyurt mimari yapılarında görülen taş bezemeler: çarklfelek-papatya tekeri örneği. II. Uluslararası Akdeniz'de Güzel Sanatlar Sempozyumu ve Kültür Sanat Çalıştayı'nda sunulan bildiri, Akdeniz Üniversitesi, Antalya.

Veith, W. J. (2009, 3 Haziran). The lion beast of Daniel 7 [Blog yazıs1]. Erişim adresi: http://amazingdiscoveries.org/S-deception_end-time_Antichrist_lion_wings. 


\section{Görsel Kaynakçası}

Fotoğraf 1. Gül, M. F. (Sanatçı). (2011). Eski(meyen) Aksaray fotoğrafları [Fotoğraf]. Aksaray: Aksaray Sanayi ve Ticaret Odasi.

Fotoğraf 2. Aktokat, N. (2014). Güzelyurt ilçesi [Fotoğraf]. Erişim Adresi: http://guzelyurt.meb.gov.tr/www/ilcemiz/kategori/7

Fotoğraf 3. Ayçin, F., Salman, Ş., Yeğen, A., Ulu Kurtaran, A., Karaköy, G., Ok, Ö. (2010). Kültür envanteri (Aksaray-Güzelyurt-1). Aksaray: Aksaray Valiliği İl Kültür ve Turizm Müdürlüğü.

Fotoğraf 14. Borchhardt, K. (Sanatçı). (2014). Tanrıça Tanit'in farklı tasvirleri [Resim]. Erişim adresi: https://journeyingtothegoddess.wordpress.com/.

Fotoğraf 20. Lesser, K. (Araştırmacl). Asher'in sembolü. (Resim). Erişim adresi: http://www.peelapom.com/spirituality/wheel-of-the-year/shevat-tribe/

\section{EK 1: Çizimler}

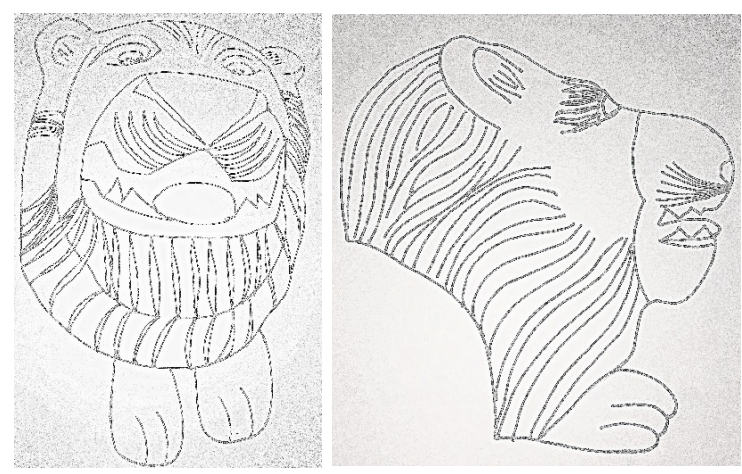

Çizim 1. Sivil mimari yapıda görülen, elle şekillendirme yöntemi ile yapılmış aslan başı figürü

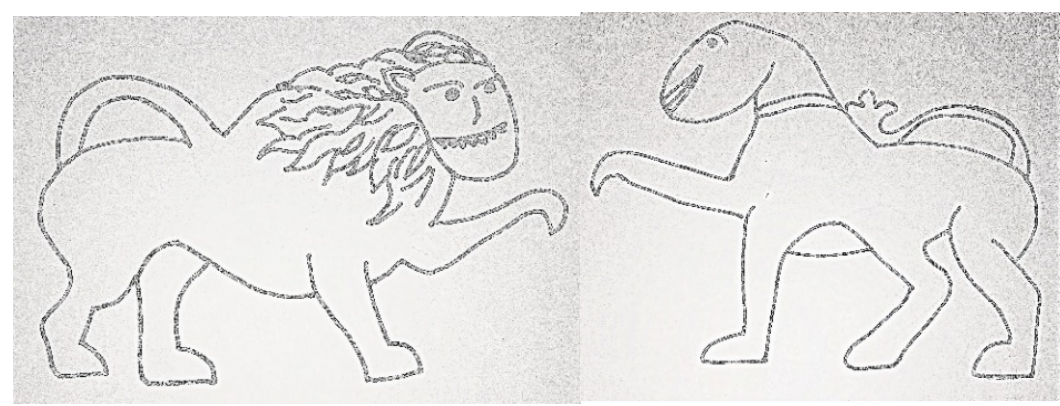

Çizim 2. Veysel Dik'in evinde yer alan karşılıklı boğa ve aslan figürü.

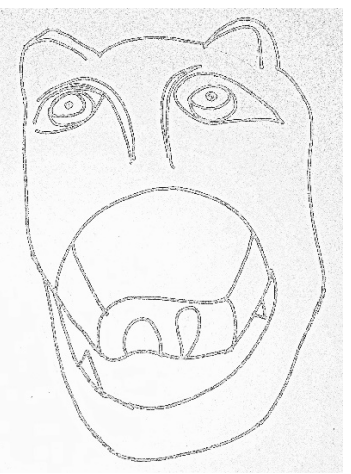

Çizim 3. Elle şekillendirme yöntemi ile yapılmış boğa başı 


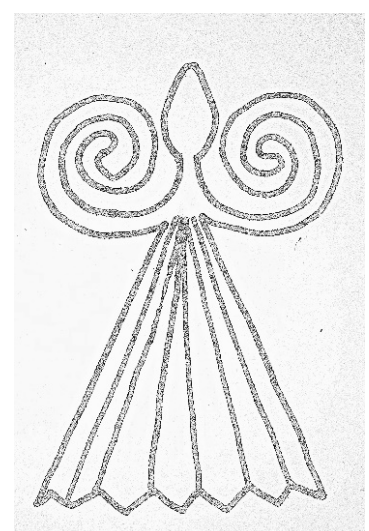

Çizim 4. Tanrıça Tanit figürü
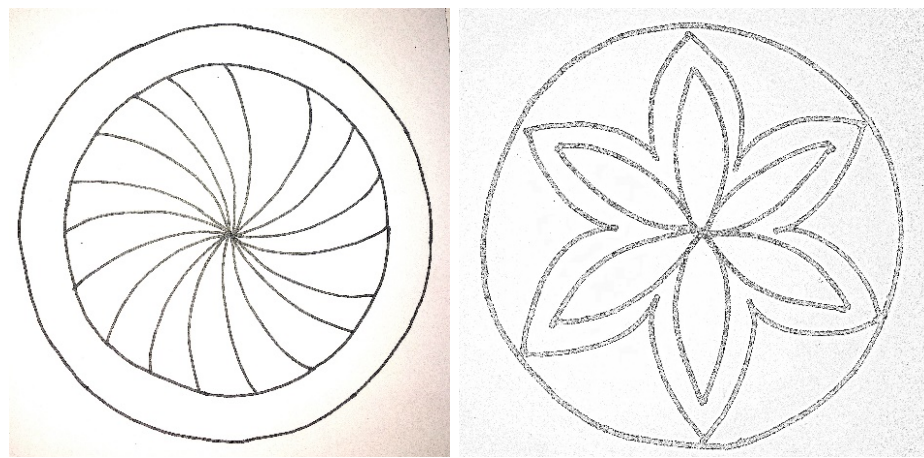

Çizim 5. Çarkıfelek ve Papatya Tekeri figürü.

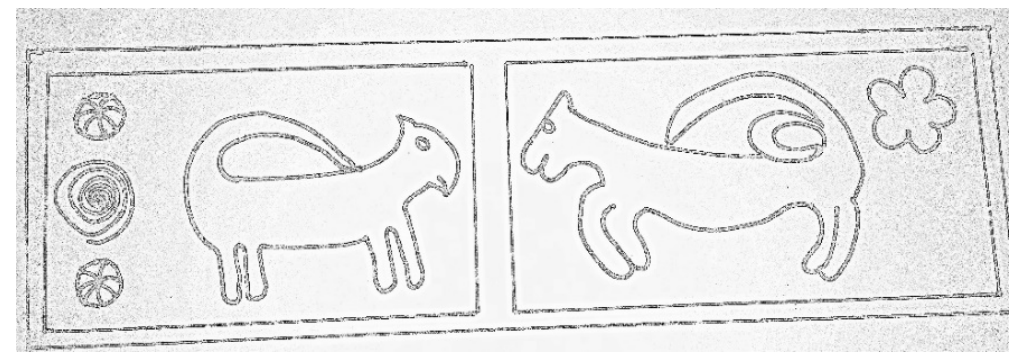

Çizim 6. Kilise Cami'nin giriş yarım sütununda yer alan taş kabartma aslan ve boğa figürü.

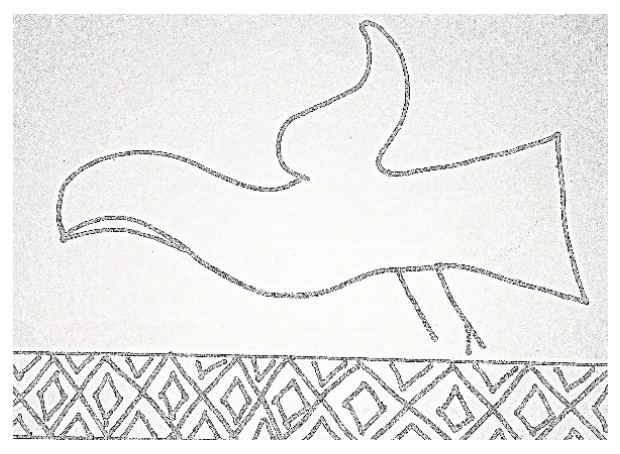

Çizim 7. Kilise Camii girişinde yer alan yarım sütunlarda görülen güvercin figürü. 


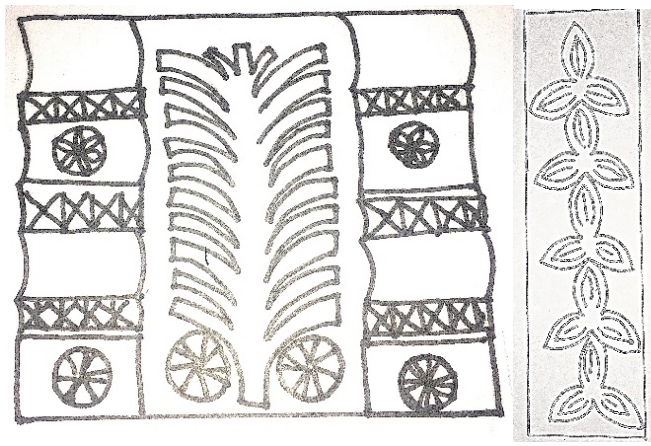

Çizim 8. Sivil mimari yapılarda görülen palmiye ve zeytin yaprağı figürü. 